\title{
BUDGET DEFICIT SUSTAINABILITY: AN APPLICATION TO TURKEY
}

\section{Zuhal Ergen $^{a}$ iD, Esin Güzhan ${ }^{a}$}

\begin{abstract}
In this study, sustainability of budget deficits in Turkey is examined empirically for the period from January 2006 to September 2020, using time series techniques based on monthly data, under the intertemporal budget constraint approach. In the analysis phase, the Johansen cointegration method was used for the long-term relationship of the series. Analysis results indicated that income and expenditure series are not cointegrated. It is concluded that budget policies for the period under consideration in Turkey are unsustainable; therefore, the applied fiscal policies should be reviewed.
\end{abstract}

Keywords: Budget deficit, sustainability, intertemporal budget constraint, Turkey JEL Classification: H30, H50, H60

\section{Introduction}

Budget deficit can be defined as budget revenues staying below budget expenditures for one year. While there are different definitions of sustainability of budget deficits, Slack and Bird (2004) point out that fiscal sustainability can be defined as the ability of a government to cover its expenditures from its revenues, regardless of transfers or borrowing. Edwards (2002) says that an economy achieves fiscal sustainability when the ratio of public sector debt to GDP is stable and consistent with the overall demand for government bonds, both domestic and foreign, and he adds that an important product of public sector sustainability analysis is the calculation of the primary balance of the public sector in line with a sustainable and stable debt-to-GDP ratio. The Treasurer of the Commonwealth of Australia (2002) also refers to fiscal sustainability as the ability to manage the government's finances so that it can meet its spending commitments now and in the future.

One of the most striking macroeconomic developments in the last four decades has been the increase and persistence of large fiscal deficits in some countries (such

a Cukurova University, Faculty of Economics and Administrative Sciences, Department of Finance, Adana, Turkey

Email: zergen@cu.edu.tr 
as the USA, Argentina, Brazil, New Zealand and Greece). Increasing public debt has been a major concern for both politicians and researchers, as it is an essential source of macroeconomic instability and even economic crises such as the foreign debt crisis and hyperinflation. One of the important conditions for sustainability of economic growth is fiscal discipline and strong fiscal position and sustainability of this position; for this reason, countries have adopted major fiscal reforms, institutional changes that strengthen fiscal rules and procedures for sustainability in the wake of external debt crises. To ensure fiscal consolidation in the euro area, the annual budget deficit should not exceed 3\% of their GDP and their total debt stocks should not exceed $60 \%$ of their GDP for countries to join the European Union economic and monetary union instituted by the Maastricht Agreement. It is also among the steps that they have to take to comply with the criteria (Woo, 2006). However, despite all these, when looking at the situation over the years, it is seen that sustainability is a recurring issue for many developed and developing countries; therefore, budget sustainability is an issue that needs to be addressed.

It is possible to investigate the sustainability of budget policies within the framework of the intertemporal budget constraint approach. The basic idea of the intertemporal budget constraint approach is that when the government has a budget deficit, it promises to provide a sufficient amount of surplus in the future to pay the accumulated debt and the expected future primary expenditures do not exceed the sum of all discounted revenues, including seigniorage (Baglioni and Cherubini, 1993).

The purpose of this study is to reveal whether the budget deficit was sustainable in Turkey between January 2006 and September 2020 on the basis of Hakkio and Rush's (1991) explanations of the sustainability of budget deficits, based on the intertemporal budget constraint approach, and to examine the fiscal policy scenarios that make it sustainable. In parallel with the recent increase in the budget deficits of some macroeconomic imbalances in Turkey, the expectation that these deficits may not be sustainable anymore and the lack of sufficient evidence regarding the sustainability of the budget deficits have inspired this study. The study contributes to the literature in several points. The period we deal with in the study starts from the date of transition to the general budget in Turkey. In 2006, Turkey switched to analytical budget classification with the Public Financial Management and Control Act no. 5018 and changed the consolidated budget definition used until that year with the general budget definition. With some changes in the structure of the budget, considering the consolidated budget and general budget data together as a single time series has created various technical drawbacks. From this point of view, our study uses budget data and analyses financial sustainability by taking this situation into account. However, most of the studies done for Turkey in recent years have ignored this distinction. 
The present study differs from other studies in that it presents the macroeconomic distortions and political and financial implementations which caused the budget deficits to follow a problematic trend and disrupted the fiscal discipline in Turkey in recent years and also differs in that it shows that these deficits are unsustainable, unlike most studies that have investigated the sustainability of budget deficits in Turkey and stated that they are sustainable. The study also includes a rich and detailed literature review for Turkey as well as for other countries.

The organization of this study is as follows: Section 2 presents the trend of budget deficits in Turkey; Section 3 presents the literature review; Section 4 contains the theoretical framework regarding the intertemporal budget constraint; Section 5 presents the data set, the methods and the analysis results; finally, the last section contains conclusions and suggestions.

\section{Overview of Budget Deficits in Turkey}

Budget deficits in Turkey have been an important problem especially since the 1980s. While the 24 January Stability Decisions taken in 1980 were of great importance for the Turkish economy, one of the targets was to reduce the share of the public sector in the economy and to strengthen the financial structure. Although it was aimed to achieve positive developments in the budget deficits, in the 1980s, the deficit problem could not be solved and the difference between public revenues and expenditures widened even further (Kepenek and Yentürk, 2003). As seen in Figure 1, while the share of budget deficits in GNP was $1.5 \%$ in 1982, this share increased to $3.5 \%$ in 1987.

\section{Figure 1: Ratios of budget deficits to GNP (\%) (1982-2005)}

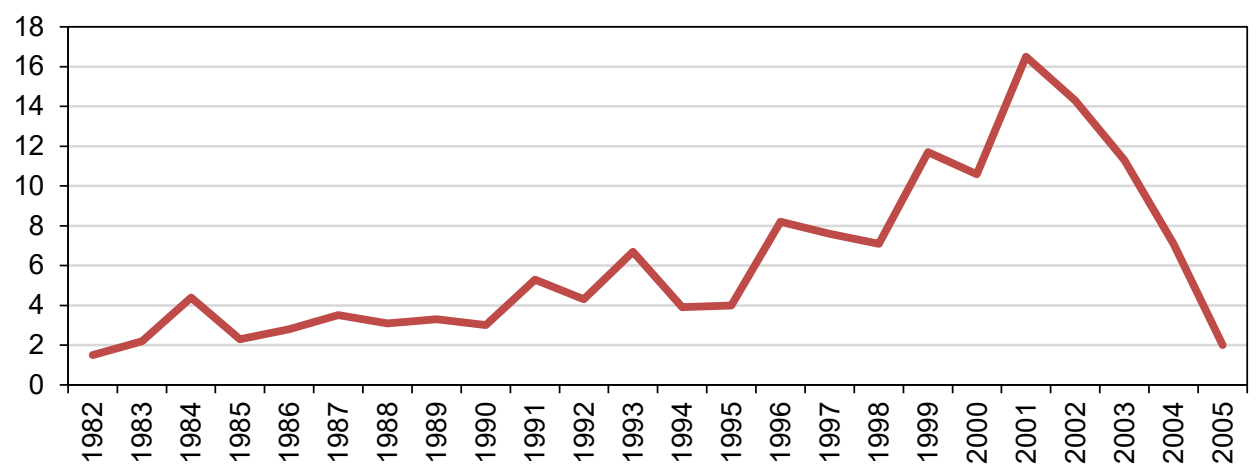

Source: Consolidated budget data from the Ministry of Treasury and Finance of the Republic of Turkey (https://www.hmb.gov.tr/kamu-finansmani-istatistikleri) 
It is possible to say that since the 1990 s, the obligation of borrowing with high interest increased the budget deficits, and the share of the budget deficit increased to $6.7 \%$ of the GNP in 1993, and finally the 1994 economic crisis was experienced, the most important reason for which was the public financing deficit. In mid-1994, Turkey accepted the IMF stand-by agreement and suppressed the economic crisis but the GNP share of the budget deficit, which was $7.1 \%$ in the previous year, increased to $10.6 \%$ in 1999 . Finally, in 1999, Turkey signed a stand-by agreement with the IMF aimed at solving the public sector imbalances; however, the budget deficits reached 29.036 million TL and the share of the budget deficit reached $16.5 \%$ in 2001, hitting its highest level ever. Thus, the IMF programme failed (Ucal and Alıc1, 2010).

The Transition Programme to a Strong Economy, launched in 2001, was aimed to prevent the public debt from reaching unsustainable levels and the government reaching a position to seek extraordinary foreign debt. In addition, the Public Financial Management and Control Act no. 5018, which came into force in May 2005, was aimed to bring the public deficits to a controllable level to a certain extent. Finally, the positive developments of the effective fiscal policies were reflected in the budget values between 2002-2007 (World Bank, 2014). After 2001, the ratio of budget deficit to GNP decreased until 2008. The share of primary surplus in GNP, which was $4.3 \%$ in 2002, reached $7.4 \%$ in 2005. As seen in Figure 1, the share of budget deficit in GNP decreased to 2\% in 2005.

As a consequence of the 2008 global crisis, the budget deficit increased to 52.761 million TL in 2009, and the ratio of budget deficit to GDP increased from $1.7 \%$ in 2008 to $5.2 \%$ in 2009 , but in the next few years the share of budget deficits in GDP decreased as shown in Figure 2. Between 2010 and 2014, the ratio of budget deficits to GDP was around $1.7 \%$ on average, while the ratio of primary budget balance to GDP was $1.3 \%$ on average.

\section{Figure 2: Ratios of budget deficits to GDP (\%) (2006-2020)}

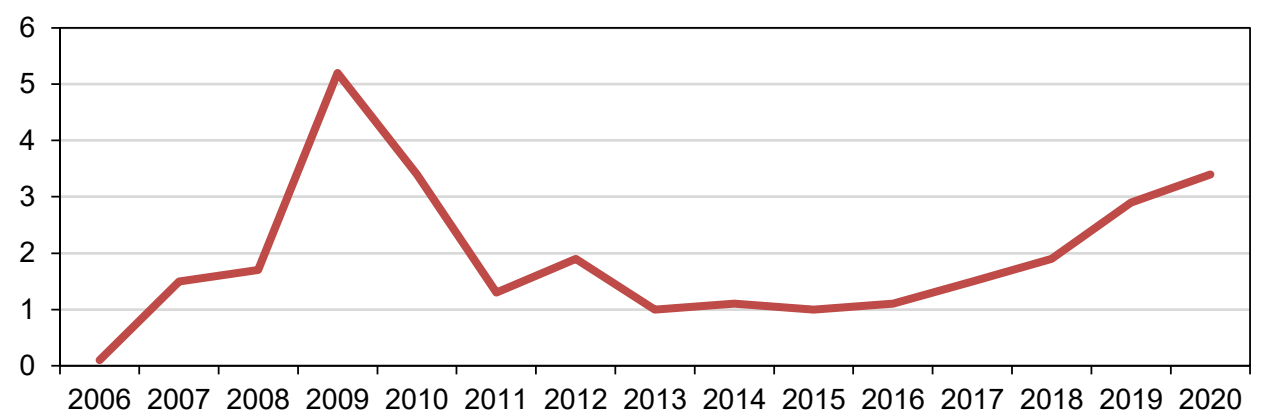

Source: Central government budget data from the CBRT EVDS (https://evds2.tcmb.gov.tr/) 


\section{Figure 3: Ratio of primary balance to GDP (\%) (2006-2020)}

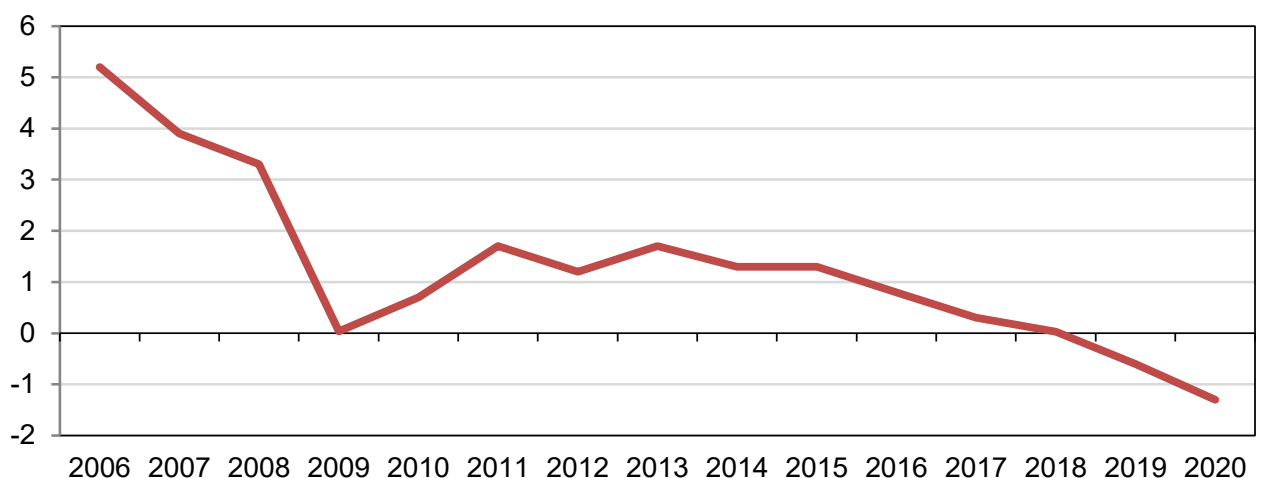

Source: Central government budget data from the Presidency of the Republic of Turkey Strategy and Budget Department (https://www.sbb.gov.tr/butce-gerekceleri/)

Looking at Figures 2 and 3, it is possible to say that it is necessary to pay particular attention to the period after 2015, because in recent years, Turkey's budget deficits and the ratio of these deficits to GDP have increased significantly and the share of primary balance in GDP has decreased. In addition to the growth-oriented policies implemented by the government in 2017, accelerating inflation, this growth of the ratio of budget deficit to GDP may be attributed to tax amnesties, tax cuts and increase in public spending. Tax amnesties were applied in 2016, 2017 and 2018, and the collection/accrual rates of tax revenues in these years are among the lowest rates ever realized in the history of the Republic of Turkey. Another issue is the burden on the budget caused by the legal framework for the establishment and operation of municipal hospitals (such as providing patient guarantees) according to the public-private partnership system and also the transition guarantee commitment on bridges and highways built. We may add that there have been increases in personnel expenses, current transfers and debt interest expenses in recent years. The ratio of personnel expenses to GDP increased in 2017 and later, and this ratio rose to 5.8\% in 2019; the share of current transfers increased in 2015 and beyond, reaching $9.3 \%$ in 2019. In addition, the primary balance-to-GDP ratio has decreased in the last few years. All these developments in recent years are among the reasons for the increase in the budget deficits in Turkey.

\section{Literature Review}

While some of the literature investigating the sustainability of budget deficits for different countries and country groups is presented in Table 1, Table 2 includes empirical studies on the subject for Turkey. 
Table 1: Empirical studies investigating sustainability of budget deficits in different countries

\begin{tabular}{|c|c|c|c|c|}
\hline Study & $\begin{array}{l}\text { Country / } \\
\text { Period }\end{array}$ & Variables & Method & Results \\
\hline $\begin{array}{l}\text { Hamilton and } \\
\text { Flavin (1986) }\end{array}$ & $\begin{array}{l}\text { ABD } \\
1960-1984\end{array}$ & $\begin{array}{l}\text { Real primary surplus and } \\
\text { real debt stock }\end{array}$ & $\begin{array}{l}\text { Dickey Fuller (DF) unit } \\
\text { root test, Generalized and } \\
\text { Restricted Flood-Garber tests }\end{array}$ & Sustainable \\
\hline Wilcox (1989) & $\begin{array}{l}\text { ABD } \\
1960-1984\end{array}$ & Debt and deficits & DF unit root test & $\begin{array}{l}\text { Sustainable } \\
\text { in 1960-1974; } \\
\text { unsustainable } \\
\text { in 1974-1984 }\end{array}$ \\
\hline $\begin{array}{l}\text { Trehan and } \\
\text { Walsh (1991) }\end{array}$ & $\begin{array}{l}\text { ABD } \\
1946-1987\end{array}$ & $\begin{array}{l}\text { Real primary surplus, real } \\
\text { debt stock }\end{array}$ & $\begin{array}{l}\text { DF and Philips-Perron (PP) } \\
\text { unit root tests }\end{array}$ & Sustainable \\
\hline $\begin{array}{l}\text { Hakkio } \\
\text { and Rush } \\
(1991)\end{array}$ & $\begin{array}{l}\text { ABD } \\
1950: 2-1988: 4\end{array}$ & $\begin{array}{l}\text { Real government } \\
\text { spending (including } \\
\text { interest payment), real } \\
\text { government revenues and } \\
\text { ratios of real income } \\
\text { and expenditures to GNP } \\
\text { and population }\end{array}$ & $\begin{array}{l}\text { Cointegrating Regression } \\
\text { Durbin-Watson, DF, ADF, } \\
\text { Constrained and Uncon- } \\
\text { strained Vector Autoregres- } \\
\text { sion, Expanded Constrained } \\
\text { and Unconstrained Vector } \\
\text { Autoregression and } \\
\text { Stock-Watson }\end{array}$ & Unsustainable \\
\hline $\begin{array}{l}\text { Quintos } \\
\text { (1995) }\end{array}$ & $\begin{array}{l}\text { ABD } \\
1947: 2-1992: 3\end{array}$ & $\begin{array}{l}\text { Real income and real } \\
\text { expenditure (including } \\
\text { interest payments) and } \\
\text { their ratio to GNP and } \\
\text { population }\end{array}$ & $\begin{array}{l}\text { Johansen-Juselius } \\
\text { cointegration test }\end{array}$ & $\begin{array}{l}\text { Strongly } \\
\text { sustainable until } \\
\text { 1980, weakly after } \\
\text { 1980; sustainable } \\
\text { when income and } \\
\text { expenditure series } \\
\text { are proportional } \\
\text { to GNP and } \\
\text { population }\end{array}$ \\
\hline $\begin{array}{l}\text { Fountas } \\
\text { and Wu } \\
(1996)\end{array}$ & $\begin{array}{l}\text { Greece } \\
1958-1992\end{array}$ & $\begin{array}{l}\text { Government revenues and } \\
\text { government expenditures } \\
\text { (including interest } \\
\text { payments) }\end{array}$ & $\begin{array}{l}\text { Engle-Granger and Gregory- } \\
\text { Hansen (1992) cointegration } \\
\text { tests }\end{array}$ & Unsustainable \\
\hline $\begin{array}{l}\text { Olekalns and } \\
\text { Cashin (2000) }\end{array}$ & $\begin{array}{l}\text { India } \\
1951-1998\end{array}$ & $\begin{array}{l}\text { Central government tax } \\
\text { revenues and expenditures }\end{array}$ & $\begin{array}{l}\text { Engle-Granger and Gregory- } \\
\text { Hansen cointegration tests }\end{array}$ & Unsustainable \\
\hline Koo (2002) & $\begin{array}{l}\text { Korea } \\
1970-1999\end{array}$ & Public deficit and debt & ADF and PP unit root tests & Sustainable \\
\hline $\begin{array}{l}\text { Arghyrou } \\
\text { and Luintel } \\
(2003)\end{array}$ & $\begin{array}{l}\text { Greece, Ireland, } \\
\text { Italy, Nether- } \\
\text { lands (different } \\
\text { period for each } \\
\text { country) }\end{array}$ & $\begin{array}{l}\text { Public spending } \\
\text { and public revenues }\end{array}$ & $\begin{array}{l}\text { Dynamic Least Squares } \\
\text { (DOLS) and Generalized } \\
\text { Least Squares (GLS) }\end{array}$ & Sustainable \\
\hline Neaime (2004) & $\begin{array}{l}\text { Lebanon } \\
\text { 1960:1-2003:4 }\end{array}$ & $\begin{array}{l}\text { Public spending and } \\
\text { public revenues }\end{array}$ & Johansen cointegration test & Unsustainable \\
\hline $\begin{array}{l}\text { Marinheiro } \\
(2005)\end{array}$ & $\begin{array}{l}\text { Portugal } \\
1903-2003\end{array}$ & $\begin{array}{l}\text { Public revenues } \\
\text { and expenditures } \\
\text { as percentage of GDP }\end{array}$ & $\begin{array}{l}\text { Johansen and Engle-Granger } \\
\text { cointegration tests }\end{array}$ & $\begin{array}{l}\text { Sustainable } \\
\text { in 1903-2003; } \\
\text { unsustainable } \\
\text { in 1975-2003 }\end{array}$ \\
\hline
\end{tabular}


Table 1: Continuation

\begin{tabular}{|c|c|c|c|c|}
\hline Study & $\begin{array}{l}\text { Country / } \\
\text { Period }\end{array}$ & Variables & Method & Results \\
\hline $\begin{array}{l}\text { Rubio, Roldan } \\
\text { and Esteve } \\
(2006)\end{array}$ & $\begin{array}{l}\text { Spain } \\
1964-2001\end{array}$ & $\begin{array}{l}\text { Ratio of government } \\
\text { revenues and expenditures } \\
\text { (including interest } \\
\text { payments) to GDP }\end{array}$ & $\begin{array}{l}\text { Threshold cointegration test } \\
\text { proposed by Hansen-Seo }\end{array}$ & Sustainable \\
\hline $\begin{array}{l}\text { Kirchgassner } \\
\text { and Prohl } \\
(2008)\end{array}$ & $\begin{array}{l}\text { Switzerland } \\
1900-2002\end{array}$ & $\begin{array}{l}\text { Ratio of government } \\
\text { revenues and expenditures } \\
\text { to GDP }\end{array}$ & $\begin{array}{l}\text { Engle-Granger and Johansen } \\
\text { cointegration tests }\end{array}$ & Sustainable \\
\hline $\begin{array}{l}\text { Stubelj and } \\
\text { Dolenc (2010) }\end{array}$ & $\begin{array}{l}27 \text { EU member } \\
\text { states } \\
2000-2010\end{array}$ & $\begin{array}{l}\text { Ratio of total budget } \\
\text { balance, public debt and } \\
\text { primary balance to GDP, } \\
\text { growth of GDP, nominal } \\
\text { interest rate on public debt }\end{array}$ & $\begin{array}{l}\text { Analysis of variance } \\
\text { (ANOVA test) }\end{array}$ & $\begin{array}{l}\text { Sustainable } \\
\text { in } 2000-2008 \text { but } \\
\text { unsustainable } \\
\text { in } 2009-2010 \\
\text { for most countries }\end{array}$ \\
\hline Mercan (2014) & $\begin{array}{l}\text { OECD countries } \\
1980: 1-2012: 4\end{array}$ & $\begin{array}{l}\text { Ratio of general } \\
\text { government revenues and } \\
\text { general government total } \\
\text { expenditures to GDP }\end{array}$ & $\begin{array}{l}\text { Panel cointegration test with } \\
\text { multiple structural breaks } \\
\text { developed by Basher and } \\
\text { Westerlund }\end{array}$ & $\begin{array}{l}\text { Weakly } \\
\text { sustainable }\end{array}$ \\
\hline $\begin{array}{l}\text { Alagidede and } \\
\text { Twenebohah } \\
\text { (2015) }\end{array}$ & $\begin{array}{l}\text { Six Latin } \\
\text { American } \\
\text { countries } \\
\text { 1990-2012 }\end{array}$ & $\begin{array}{l}\text { Ratio of public revenues } \\
\text { and expenditures to GDP }\end{array}$ & $\begin{array}{l}\text { Perron, Kao } \\
\text { and Westerlund } \\
\text { cointegration tests }\end{array}$ & $\begin{array}{l}\text { Weakly } \\
\text { sustainable }\end{array}$ \\
\hline $\begin{array}{l}\text { Baharumshah, } \\
\text { Soon and Lau } \\
(2017)\end{array}$ & $\begin{array}{l}\text { Malaysia } \\
\text { 1980:1-2014:3 }\end{array}$ & $\begin{array}{l}\text { Ratio of public debt and } \\
\text { budget balance to GDP }\end{array}$ & $\begin{array}{l}\text { Markov constant } \\
\text { autoregressive } \\
\text { heteroscedasticity error } \\
\text { correction model }\end{array}$ & Sustainable \\
\hline $\begin{array}{l}\text { Brady and } \\
\text { Magazzino } \\
(2019)\end{array}$ & $\begin{array}{l}\text { Italy } \\
1862-2013\end{array}$ & $\begin{array}{l}\text { Ratio of government } \\
\text { revenues and expenditures } \\
\text { to GDP }\end{array}$ & $\begin{array}{l}\text { Engle-Granger, Gregory- } \\
\text { Hansen, Autoregressive Dis- } \\
\text { tributed Lags (ARDL), Banerje, } \\
\text { Dolado and Mestre (1998) and } \\
\text { Boswijk and Doornik (2005) } \\
\text { cointegration tests }\end{array}$ & $\begin{array}{l}\text { Sustainable } \\
\text { in 1862-1913; } \\
\text { weakly sustainable } \\
\text { in 1947-2013 and } \\
\text { unsustainable } \\
\text { in 1862-2013 }\end{array}$ \\
\hline $\begin{array}{l}\text { Nzimande } \\
\text { and Ngalawa } \\
(2019)\end{array}$ & $\begin{array}{l}13 \text { countries } \\
\text { that are mem- } \\
\text { bers of South- } \\
\text { ern African } \\
\text { Development } \\
\text { Community } \\
\text { 1980-2014 }\end{array}$ & $\begin{array}{l}\text { Public revenues and } \\
\text { expenditures }\end{array}$ & $\begin{array}{l}\text { Westerlund (2007) } \\
\text { cointegration test }\end{array}$ & Sustainable \\
\hline $\begin{array}{l}\text { Bustrav and } \\
\text { Mackiewicz } \\
(2020)\end{array}$ & $\begin{array}{l}\text { Sweden, United } \\
\text { Kingdom, USA } \\
\text { 1792-2012 }\end{array}$ & Ratio of public debt to GDP & $\begin{array}{l}\text { ADF, KPSS, Supremum ADF } \\
\text { and Generalised Sequential } \\
\text { ADF tests }\end{array}$ & Sustainable \\
\hline $\begin{array}{l}\text { Lian Chua et al. } \\
\text { (2021) }\end{array}$ & $\begin{array}{l}\text { Sri Lanka } \\
1961-2017\end{array}$ & $\begin{array}{l}\text { Ratio of real debt and } \\
\text { primary surplus to GDP }\end{array}$ & $\begin{array}{l}\text { Sustainability test of Bohn's } \\
\text { model-based Nguyen et al. } \\
\text { (2017) time-varying parameter } \\
\text { model-based, Aldama and } \\
\text { Creel }(2017,2019) \text { regime- } \\
\text { switching model-based }\end{array}$ & $\begin{array}{l}\text { Unsustainable } \\
\text { in 1978-1983 } \\
\text { and 1986-1990; } \\
\text { sustainable } \\
\text { in other periods }\end{array}$ \\
\hline
\end{tabular}

Source: Authors' own elaboration based on studies cited 
Table 2: Empirical studies investigating sustainability of budget deficits in Turkey

\begin{tabular}{|c|c|c|c|c|}
\hline Study & Period & Variables & Method & Results \\
\hline $\begin{array}{l}\text { Özdemir } \\
(2004)\end{array}$ & $\begin{array}{l}1988: 4- \\
2000: 4\end{array}$ & $\begin{array}{l}\text { Ratio of public debt } \\
\text { to GDP }\end{array}$ & $\begin{array}{l}\text { ADF, PP and Mackinnon } \\
\text { and Phillips-Schmidt unit } \\
\text { root tests }\end{array}$ & Unsustainable \\
\hline $\begin{array}{l}\text { Telatar et al. } \\
(2004)\end{array}$ & $1980-2001$ & Primary budget surplus & $\begin{array}{l}\text { Bohn model, Markov } \\
\text { switching model }\end{array}$ & Unsustainable \\
\hline $\begin{array}{l}\text { Kuştepeli } \\
\text { and Önel } \\
(2005)\end{array}$ & $1970-2003$ & $\begin{array}{l}\text { Government revenues } \\
\text { and government } \\
\text { expenditures (including } \\
\text { interest payments) }\end{array}$ & $\begin{array}{l}\text { Johansen and Gregory- } \\
\text { Hansen cointegration } \\
\text { tests }\end{array}$ & Weakly sustainable \\
\hline $\begin{array}{l}\text { Gürbüz et al. } \\
(2007)\end{array}$ & $1988-2002$ & $\begin{array}{l}\text { Government revenues, } \\
\text { government expendi- } \\
\text { tures, public debt, primary } \\
\text { balance and their ratio } \\
\text { to GDP }\end{array}$ & $\begin{array}{l}\text { DF, PP unit root tests, } \\
\text { Johansen cointegration } \\
\text { test }\end{array}$ & $\begin{array}{l}\text { Public debt and deficits } \\
\text { generally unsustainable }\end{array}$ \\
\hline $\begin{array}{l}\text { Kia } \\
(2008)\end{array}$ & $1967-2001$ & $\begin{array}{l}\text { Real government } \\
\text { revenues and real } \\
\text { government expenditures }\end{array}$ & $\begin{array}{l}\text { Gregory-Hansen } \\
\text { cointegration test }\end{array}$ & Unsustainable \\
\hline $\begin{array}{l}\text { Payne et al. } \\
(2008)\end{array}$ & 1968-2004 & $\begin{array}{l}\text { Ratio of government } \\
\text { revenues, government } \\
\text { expenditures and budget } \\
\text { balance to GNP }\end{array}$ & $\begin{array}{l}\text { ADF, PP, KPSS, Perron } \\
\text { (1997) unit root tests; } \\
\text { Johansen-Juselius, } \\
\text { Gregory- Hansen } \\
\text { and Stock-Watson } \\
\text { cointegration tests and } \\
\text { Threshold Autoregressive } \\
\text { (TAR) and Momentum } \\
\text { Threshold Autoregressive } \\
\text { methods (MTAR) tests }\end{array}$ & $\begin{array}{l}\text { Budget deficit sustainable } \\
\text { in long term but attention } \\
\text { should be paid to size } \\
\text { of budget deficit }\end{array}$ \\
\hline $\begin{array}{l}\text { Ucal } \\
\text { and Alıcı } \\
(2010)\end{array}$ & $\begin{array}{l}\text { 1989:1- } \\
2008: 12\end{array}$ & $\begin{array}{l}\text { Real government reve- } \\
\text { nues and real government } \\
\text { expenditures (including } \\
\text { interest payments on } \\
\text { public debt) }\end{array}$ & $\begin{array}{l}\text { Johansen cointegration } \\
\text { method }\end{array}$ & $\begin{array}{l}\text { Weakly sustainable until } \\
\text { 2001; strongly sustainable } \\
\text { after } 2001\end{array}$ \\
\hline $\begin{array}{l}\text { Peker } \\
\text { and Göçer } \\
(2012)\end{array}$ & $\begin{array}{l}\text { 1987:1- } \\
2010: 12\end{array}$ & $\begin{array}{l}\text { Central government real } \\
\text { budget revenues and } \\
\text { central government real } \\
\text { budget expenditures } \\
\text { (including interest } \\
\text { payments) }\end{array}$ & $\begin{array}{l}\text { Bounds test approach } \\
\text { developed by Pesaran } \\
\text { et al. (2001) }\end{array}$ & $\begin{array}{l}\text { Weakly sustainable } \\
\text { in the periods 1987:1- } \\
\text { 1994:3, 1994:4-2001:1, } \\
\text { 1987:1 -2010:12; strongly } \\
\text { sustainable in the period } \\
\text { 2001:2-2010:12 }\end{array}$ \\
\hline $\begin{array}{l}\text { Akar } \\
(2014)\end{array}$ & $1950-2012$ & $\begin{array}{l}\text { Ratio of total budget } \\
\text { revenue and expenditures } \\
\text { to GDP }\end{array}$ & $\begin{array}{l}\text { Gregory-Hansen } \\
\text { cointegration and TAR } \\
\text { and MTAR methods } \\
\text { of Enders-Siklos (2001) }\end{array}$ & Weakly sustainable \\
\hline $\begin{array}{l}\text { Altun } \\
(2017)\end{array}$ & $1950-2015$ & $\begin{array}{l}\text { Consolidated budget } \\
\text { income-expense } \\
\text { difference }\end{array}$ & $\begin{array}{l}\text { ADF, PP, Lee and } \\
\text { Strazicich, Fourier KSS } \\
\text { unit root; Harvey et al. } \\
\text { (2008) linearity tests }\end{array}$ & Sustainable \\
\hline
\end{tabular}


Table 2: Continuation

\begin{tabular}{|c|c|c|c|c|}
\hline Study & Period & Variables & Method & Results \\
\hline $\begin{array}{l}\text { Kapkara and } \\
\text { Büyükakın } \\
(2018)\end{array}$ & $\begin{array}{l}2006: 1- \\
2018: 9\end{array}$ & $\begin{array}{l}\text { Budget revenues } \\
\text { and primary budget } \\
\text { expenditures }\end{array}$ & $\begin{array}{l}\text { ARDL cointegration } \\
\text { technique }\end{array}$ & Unsustainable \\
\hline $\begin{array}{l}\text { Akkuş and } \\
\text { Durmaz } \\
\text { (2019) }\end{array}$ & $1930-2016$ & $\begin{array}{l}\text { Ratio of budget revenues } \\
\text { and budget expenditures } \\
\text { (including interest } \\
\text { payments) to GDP }\end{array}$ & $\begin{array}{l}\text { Johansen cointegration } \\
\text { and Hatemi-J and } \\
\text { Irandoust hidden } \\
\text { cointegration method }\end{array}$ & Weakly sustainable \\
\hline $\begin{array}{l}\text { Göçer } \\
\text { and Aslan } \\
(2020)\end{array}$ & $\begin{array}{l}\text { 2006:1- } \\
2019: 1\end{array}$ & $\begin{array}{l}\text { Central government real } \\
\text { budget revenues and } \\
\text { central government real } \\
\text { budget expenditures } \\
\text { (including interest } \\
\text { payments) }\end{array}$ & $\begin{array}{l}\text { Hatemi-J (2008) } \\
\text { cointegration test with } \\
\text { break }\end{array}$ & Strongly sustainable \\
\hline Belke (2021) & $\begin{array}{l}2006- \\
2019\end{array}$ & $\begin{array}{l}\text { Real income and } \\
\text { real expenditures } \\
\text { of municipalities }\end{array}$ & $\begin{array}{l}\text { Westerlund (2007) panel } \\
\text { cointegration test based } \\
\text { on error correction } \\
\text { model }\end{array}$ & $\begin{array}{l}\text { Financial structures of } 81 \\
\text { provincial municipalities } \\
\text { unsustainable }\end{array}$ \\
\hline
\end{tabular}

Source: Authors' own elaboration based on studies cited

When we look at the literature that examines budget deficits or, in a broader sense, fiscal sustainability, we see that sustainability is examined with a number of sustainability approaches such as the accounting approach, the intertemporal budget constraint approach and the Bohn approach. We may say that most of the studies in Tables 1 and 2 have focused on the sustainability approach, which is alternatively referred to as the present value borrowing constraint or the intertemporal budget constraint in the literature. The intertemporal budget constraint states that the government balances the intertemporal budget by equating the discounted value of the expected future budget surplus with the current market value of its debt, and is based on the assumption that the government will not resort to Ponzi scheme financing while doing this.

When Tables 1 and 2 are examined, it is observed that the periods, variables and methods used in these studies in which budget deficits or, more generally, fiscal sustainability are investigated, differ. However, we may say that these studies may be classified as studies involving the stagnation analysis of fiscal variables such as public debt and budget deficit, studies on the relationship between primary surplus and public debt (Bohn approach), and empirical studies determining the relationship between public revenues and public expenditures. In addition, we may say that a single method may be used to investigate financial sustainability, or more than one method may be used together in these studies. When the studies are examined; we may say that within the framework 
of the present value constraint, the foundation of which was laid by Hamilton and Flavin (1986), there are studies investigating whether variables such as debts, deficits or primary surplus converge to the average value using unit root tests. In the following years, studies based on Hakkio and Rush (1991) and investigating the long-term relationship between sustainability, public revenue and public expenditures with various cointegration tests were also dominant in the intertemporal budget constraint. In summary, it has been seen that it is not sufficient to investigate sustainability with unit root tests by testing the convergence of public deficits, public debts and primary surpluses to the mean value using various unit root tests over time and we may say that the relationship between sustainability, public income and expenditure variables has also been investigated using very diverse methods such as cointegration, impulse response analysis and the Dynamic Least Squares Method. When Tables 1 and 2 are examined, it is seen that there are also studies on the relationship between primary surplus and public debt (Bohn model).

Using a linear regression, Bohn (1998) shows that the positive response of primary surpluses to an increase in public debt should be treated as a sufficient condition for debt sustainability (Telatar et al., 2004).

If we look at the advantages and disadvantages of the methods in Tables 1 and 2, the advantage of the Bohn approach is that it systematizes past experience and models and presents financial accounts in a more realistic way; the disadvantage of this approach may be that since Bohn uses a fixed-parameter model, the economic decision-making units in any country have a primary surplus for the next period at the same level as the previous period, depending on the implicit assumption that the intentions of the financial authorities do not change during the analysed period.

Again, when we look at the studies in Tables 1 and 2 investigating sustainability with stagnation tests and cointegration tests within the framework of the intertemporal government budget constraint approach, it is seen that the analyses made using stagnation tests over time may be insufficient, as analyses using this method may require longer-term data and these tests are not supported by an inference about whether sustainability is weak or strong, and for these reasons, cointegration methods and/or both methods are preferred.

Moreover, Bohn argues that intertemporal budget constraint tests that reduce future primary balances to risk-free rates are specified incorrectly because the correct discounting factors depend on the state-contingent equilibrium pricing kernel, and shows that the misidentification error leads to false inferences that deny financial solvency despite its actual existence. Bohn also argues that testing debt sustainability is futile given that intertemporal government budget constraints are valid under very weak conditions. Given the disadvantage of the traditional debt sustainability approach, Bohn (2007) argues that describing in data the dynamics of fiscal reaction functions which support financial solvency 
is a natural approach to understanding deficit problems (Lian Chua et al., 2021). However, despite Bohn's approach, many studies continue to be carried out within the framework of the traditional intertemporal budget constraint approach, including in recent years.

In this respect, when Table 1 is examined, we may say that there are studies investigating sustainability within the framework of financial response functions. In addition, we may say that inclusion of regime change in the analysis of fiscal policy using the Markov switching model and testing of its effects on long-term fiscal sustainability have been discussed, especially in recent years. On this subject, it may be recommended to see Aldama and Creel (2019) and Lian Chua et al. (2021).

When the results in Tables 1 and 2 are analysed, we may say that if the results point to the existence of sustainability (weak or strong), it may be suggested to improve or change the fiscal policies implemented in the case of weak sustainability; in the case of strong sustainability, it may be argued that the policies implemented can be continued. It should be taken into account that the financial policies applied should be changed where no sustainability is concluded.

When we look at the literature on the sustainability of budget deficits, it is seen that there is a wide spectrum; however, the fact that the studies on this subject related to Turkey, especially those made by taking into account the changing budget calculations, are quite inadequate has also been a source of inspiration for the present study. In terms of the period it covers, this study contributes to the literature by avoiding the technical problems that may occur if considering the consolidated budget and general budget data as a single time series.

\section{Theoretical Structure of Intertemporal Budget Constraint Approach}

Hakkio and Rush (1991) show a budget constraint equation that the government may encounter in any period, assuming that all government bonds have one term for the sake of simplicity, with Equation (1) for a single period (period $t$ ):

$$
G_{t}+\left(1+i_{t}\right) B_{t-1}=R_{t}+B_{t}
$$

In Equation (1), $B_{t}$ represents the government's funds obtained by issuing debt securities, $R_{t}$ is the government's revenue, $i_{t}$ is the interest rate (one period), and $G_{t}$ is the government's purchase value of goods and services and transfer payments. $G_{t}$ does not include interest payments on debt. These interest payments and principal to be repaid are the second term on the spending side. Hakkio and Rush (1991) argue that it is possible to obtain the intertemporal budget constraint by solving the budget constraint in Equation 1 
for future periods, and accepting $r_{t}$ as the discount factor, they expressed the intertemporal budget constraint as in Equation 2:

$$
\mathrm{B}_{0}=\sum_{t=1}^{\infty} r_{t}\left(R_{t}-G_{t}\right)+\lim _{n \rightarrow \infty} r_{n} B_{n}
$$

In Equation 2, $r_{t}=\prod_{s=1}^{t} \beta_{s}$ and $\beta_{s}=1 /\left(1+i_{s}\right)$. The equivalence means that the present value of the public debt stock, $B_{0}$, will be equal to the sum of the present value of all expected future surpluses, $\left(\sum_{t=1}^{\infty} r_{t}\left(R_{t}-G_{t}\right)\right)$, and the limit term, which represents the asymptotic expected value of the public debt. In this equation, when the limit is equal to zero, the debt stock, $B_{0}$, becomes equal to the present value of the government's budget surpluses and we can say that in the long run, the Ponzi condition will not be realized and the government will not go into new borrowing to finance its deficits. Therefore, if the limit term in Equation 2 is zero, the budget deficit is sustainable; when the limit value is not equal to zero, it is stated that the sustainability of budget deficits is difficult. Hakkio and Rush assumed that Equation 2 was not sufficiently suitable to test the sustainability of the intertemporal budget constraint. They assumed that the real interest rate is stationary around an average value and obtained Equation 3 by subtracting the term $i \beta_{t-1}$ from both sides of Equation 1:

$$
E_{t}+(1+i) B_{t-1}=R_{t}+B_{t}
$$

Here, $E_{t}=G_{t}+\left(i_{t}-i\right) B_{t-1}$. By solving Equation 3 forward, Equation 4 is obtained, where $\beta=1 /(1+i)$.

$$
B_{t-1} \sum_{j=0}^{\infty} \beta^{j+1}=\left(R_{t+j}-E_{t+j}\right)+\lim _{j \rightarrow \infty} \beta^{j+1} B_{t+j}
$$

Equation 4 can be written as follows after much laborious mathematical manipulation:

$$
G_{t}+i_{t}+B_{t-1}=R_{t}+\sum_{j=0}^{\infty} \beta^{j-1}\left(\Delta R_{t+j}-\Delta E_{t+j}\right)+\lim _{j \rightarrow \infty} \beta^{j+1} B_{t+j}
$$

Let $G G$ represent the total government spending on goods and services, transfer payments and interest on the $\operatorname{debt}\left(G G_{t}=G_{t}+i B_{t-1}\right) ; G G$ then equals the left-hand side of Equation (5). Hakkio and Rush (1991) assumed that $R$ and $E$ are non-stationary $\left(R_{t}=\alpha_{1}+R_{t-1}+\varepsilon_{1 t}\right.$ and $E_{t}=\alpha_{2}+E_{t-1}+\varepsilon_{2 t}$ ), so that $\Delta R_{t}$ and $\Delta E_{t}$ are stationary.

Equation 5 can be written as follows:

$$
G G_{t}=\alpha+R_{t}+\lim _{j \rightarrow \infty} \beta^{j+1} B_{t}+\varepsilon_{t}
$$

In Equation $6, \alpha \equiv \sum \beta^{j-1}\left(\alpha_{1}-\alpha_{2}\right)=[(1+i) / i]\left(\alpha_{1}-\alpha_{2}\right)$ and $\varepsilon_{t} \equiv \sum \beta^{j-1}\left(\varepsilon_{1 t}-\varepsilon_{2 t}\right)$. This equivalence forms the basis for testing the sustainable fiscal deficit hypothesis. It is 
possible to reach Equation 7, which assumes the transversality condition for the budget constraint (the limit term specified in Equation 6 is zero):

$$
R_{t}=\alpha+b G G_{t}+\varepsilon_{t}
$$

This is the basic equation used to test the sustainability of the intertemporal budget constraint. In this equation, if $G G$ (government expenditures including interest payment) and $R$ (government revenues) are cointegrated and $b=1$, the intertemporal budget constraint can be achieved, budget deficits are sustainable; if the variables $G G$ and $R$ are not cointegrated, it can be said that the intertemporal budget constraint cannot be achieved and the deficits are not sustainable. Hakkio and Rush, on the other hand, show that if $G G$ and $R$ are non-stationary variables at levels, $0<b<1$ is a sufficient condition to comply with the budget constraint. Afonso (2005) summarizes the results regarding the intertemporal budget constraint with three specific notions: the absence of cointegration indicates that the fiscal deficit is not sustainable, the deficit is sustainable when there is cointegration with $b=1$ and the deficit may not be sustainable when there is cointegration with $b<1$. Based on Equation (7), there are also studies focusing on the sustainability of the budget deficit in a weak or strong form. Quintos (1995) stated that if $b=1$ and revenues and expenditures are cointegrated, the deficit sustainability is strong; if revenues and expenditures are cointegrated at $0<b<1$, the sustainability is weak.

\section{Data, Research Method and Empirical Findings}

This study investigated whether the sustainability of the deficit can be achieved in Turkey for the period from January 2006 to September 2020 by taking the model in the studies of Hakkio and Rush (1991) as a premise. The basic model to be analysed is determined as in Equation 8:

$$
\ln R_{t}=\alpha+\beta \ln G_{t}+\varepsilon_{t}
$$

Public revenues and expenditures as the central government budget revenues and central government budget expenditures, including interest payments, for the period from January 2006 to September 2020, in the form of monthly data were obtained from the Central Bank of the Republic of Turkey (CBRT) Electronic Data Dissemination System (EDDS). The series of these two variables were realised and seasonally adjusted, then the logarithms of both variables were taken.

To investigate the cointegration relationship between $\ln R$ and $\ln G$ variables, the stationarity of the series of two variables was examined first, since the variables 
must be stationary at the same order; the long-term equilibrium relationship between the two series by ensuring the same degree of stationarity of the series was analysed using the cointegration test.

$\mathrm{ADF}$ and KPSS unit root tests were used for the stationarity of the real government revenues and real government expenditures series.

The null hypothesis for the ADF test is that the series contains a unit root; the alternative hypothesis states the series is stationary (Dickey and Fuller, 1979). If the absolute value of the ADF test statistic is greater than the absolute value of the critical values obtained for various significance levels, the series is considered stationary; if it is smaller, the series is not stationary (Enders, 1995).

In the KPSS unit root test, the null hypothesis is that the series is stationary; the alternative hypothesis states that the series contains a unit root (Kwiatkowski et al., 1992). Kwiatkowski et al. (1992) propose the Lagrange Multiplier (LM) statistic to test the basic hypothesis that the series is stationary versus the alternative hypothesis that it is not stationary. If the $\eta$ value calculated the using LM test is greater than the critical value, the series is not stationary; if the $\eta$ value is less than the critical value, the series is stationary.

Table 3: ADF and KPSS unit root analysis results

\begin{tabular}{|c|c|c|c|c|c|c|}
\hline \multirow[b]{3}{*}{ Variables } & \multicolumn{4}{|c|}{ ADF } & \multirow{2}{*}{\multicolumn{2}{|c|}{ KPSS }} \\
\hline & \multicolumn{2}{|c|}{ Model A } & \multicolumn{2}{|c|}{ Model B } & & \\
\hline & $k$ & $t$ & $k$ & $t$ & $\eta_{u}$ & $\eta_{\beta}$ \\
\hline $\ln R$ & 5 & -3.12 & 7 & -0.72 & 1.65 & 0.21 \\
\hline $\ln G$ & 5 & $-3.85^{* *}$ & 5 & -0.37 & 1.68 & 0.16 \\
\hline$d \ln R$ & 6 & $-8.81^{*}$ & 6 & $-8.85^{*}$ & $0.13^{*}$ & $0.11^{*}$ \\
\hline dInG & 4 & $-12.93^{*}$ & 4 & $-12.97^{*}$ & $0.11^{*}$ & $0.10^{*}$ \\
\hline \multirow{3}{*}{$\begin{array}{lrl}\text { Critical } & 1 \% & (*) \\
\text { values } & 5 \% & (* *) \\
& 10 \% & (* * *)\end{array}$} & $1 \%$ & -4.01 & - & -3.47 & 0.74 & 0.21 \\
\hline & $5 \%$ & -3.44 & - & -2.88 & 0.46 & 0.14 \\
\hline & $10 \%$ & -3.14 & - & -2.58 & 0.35 & 0.12 \\
\hline
\end{tabular}

Note: Model A is the model that tests the unit root in trend and constant; model $B$ is the model that tests the unit root in constant. $t$ is the ADF test statistic, $k$ is the number of lags; the lags decreased from 8 and their significance was determined according to the AIC.

Source: Own calculations 
As can be seen in Table 3, two separate regression equations were examined for both $\mathrm{ADF}$ and KPSS tests. When the unit root tests are evaluated together, it is seen that the variables are not stationary at the level; however, we may say that they become stable when their first difference is taken.

Since the first differences of the variables in unit root analysis are stationary, cointegration analysis may be started. The Johansen-Juselius cointegration test was used to investigate the cointegration relationship between variables.

This method is related to the relationship between the rank of a matrix and its characteristic roots, and according to this method, it is possible to specify a $z_{t}$ vector consisting of $n$ endogenous variables as unconstrained vector autoregression (VAR) as in Equation 16 (Harris and Sollis, 2003):

$$
z_{t}=A_{1} z_{t-1}+\ldots \ldots+A_{k} z_{t-\mathrm{k}}+u_{t} \quad u_{t} \sim \mathrm{IN}(0, \Sigma)
$$

In Equation (9) each of $z(\mathrm{nx} 1)$ and $A_{i}$ are a (nxn) parameter matrix. Equation (9) can be reformulated in the form of a vector error correction model (Harris and Sollis, 2003):

$$
\Delta z_{\mathrm{t}}=\Gamma_{1} \Delta z_{t-1}+\ldots \ldots+\Gamma_{k-1} \Delta z_{t-k+1}+\prod z_{t-k}+u_{t}
$$

Here, $\Gamma_{i}=-\left(I-A_{1}-\ldots . .-A_{\mathrm{i}}\right)(i=1, \ldots, k-1)$ and $\Pi=-\left(I-A_{1}-\ldots . .-A_{k}\right)$. Specifying the system in this way provides information on both short-term and long-term adjustments for changes in $z_{t}$ through estimates of $\Gamma_{i}$ and $\prod$, respectively. It is possible to write the parameters of the $\prod$ matrix as two components in which $\Pi=\alpha \beta^{\prime}$. In this equation, $\alpha$ indicates the adjustment speed of the long-term parameter and $\beta^{\prime}$ indicates the long-term coefficient. Thus, cointegration in the equation is investigated by the rank of the $\prod$ matrix. If the rank is equal to zero, it is assumed that there is no cointegration and if the rank is greater than zero, cointegration is achieved (Harris and Sollis, 2003). Johansen and Juselius showed that the rank may be determined by "trace and maximum eigenvalue" tests. When the trace test statistic tests the null hypothesis that the number of cointegrated vectors is equal to or less than $r$ against the alternative hypothesis; the maximum eigenvalue test statistic tests the null hypothesis that the number of cointegrated vectors is $r$ against the alternative hypothesis with $r+1$ cointegrated vector. The statistical values obtained from these two tests are compared with the critical values developed by Johansen and Juselius (Maddala and Kim, 1998). Accordingly, when the maximum eigenvalue and trace test statistic values are less than the critical values, the series are not co-integrated; when they are greater, the series are cointegrated (Enders, 1995). 
Table 4: Results of trace test statistics

\begin{tabular}{l|c|c|c}
\hline Hypothesis & Trace test statistics & $\mathbf{5 \%}$ critical value & Probability value \\
\hline $\mathbf{r}=\mathbf{0}$ & 24.69 & 25.87 & 0.07 \\
\hline $\mathbf{r} \leq \mathbf{1}$ & 8.72 & 12.52 & 0.20 \\
\hline
\end{tabular}

Source: Own calculations

Table 5: Results of maximum eigenvalue test statistics

\begin{tabular}{l|c|c|c}
\hline Hypothesis & $\begin{array}{c}\text { Maximum eigenvalue } \\
\text { test statistics }\end{array}$ & $\mathbf{5 \% \text { critical value }}$ & Probability value \\
\hline $\mathbf{r}=\mathbf{0}$ & 15.96 & 19.39 & 0.15 \\
\hline $\mathbf{r} \leq \mathbf{1}$ & 8.73 & 12.52 & 0.20 \\
\hline
\end{tabular}

Source: Own calculations

The appropriate lag length for the VAR model was determined as 6 according to various information criteria. With the determination of the lag length, cointegration analysis was started. According to both the trace and the maximum eigenvalue test statistics, no cointegration at the 5\% significance level was found. The cointegration analysis performed between the variables $\ln R$ and $\ln G$ shows that hypothesis $\mathrm{H}_{0}$ that there is no cointegration between the variables is accepted and no cointegration vector is found between the variables. This shows that there is no long-term relationship between variables and budget deficits in Turkey are not sustainable for the period from January 2006 to September 2020.

This result is not consistent with most of the studies in the literature on Turkey; however, we may say that it is consistent with Özdemir (2004), Telatar et al. (2004), Kia (2008), Kapkara and Büyükakın (2018), and Belke (2021). We may also state that the results obtained in this study show consistency with the studies that take into account data from 2006 and after and especially data after 2015. We may state that the methods used in those studies (unit root test method, analysis within the framework of the Bohn model, cointegration test considering structural breaks, cointegration using the ARDL technique and panel data analysis) in which we obtained consistent results differ from the method we used in our study (Johansen cointegration). When we look at the studies made for Turkey, it is seen that the studies considering the changes made in the budget calculations with Act no. 5018 are very few. We took the changes made in the budget calculations into account. Therefore, this article differs from most of the studies investigating the sustainability of budget deficits for Turkey. 


\section{Conclusions and Recommendations}

The size and sustainability of budget deficits represent a serious problem in many countries. This is an important issue in terms of both economy and public policy. Since lack of budget control makes economic policies unable to support both macro and microeconomic levels rapidly, macroeconomic instability often increases, leading to weak growth or even growth collapses. Considering the budget deficit, which has been a serious problem in Turkey for many years, this study aimed to examine whether the budget policy in Turkey is sustainable within the framework of the intertemporal budget constraint approach.

This study examined whether intertemporal budget constraint can be achieved in Turkey for the period from January 2006 to September 2020, using a method based on Hakkio and Rush's (1991) investigation of the cointegration relationship between government expenditures including interest payments and government revenues series. The Johansen cointegration method was used to determine the cointegration relationship between the two variables. The results of the cointegration analysis indicate that there is no long-term relationship between these two variables, the budget revenues for the period under consideration cannot meet the budget expenditures and accordingly, the budget deficits are unsustainable.

The findings of the study are not surprising considering that the budget deficit in Turkey, which was 24.5 billion TL in 2015, reached 172.7 billion TL in 2020, the share of budget deficits in GDP increased from $1.1 \%$ in 2015 to $3.5 \%$ in 2020 and the primary balance-to-GDP ratio, which was $1.3 \%$ in 2015 , was $-1.3 \%$ in 2020 .

Among the public expenditure items, it is observed that while the GDP share of personnel expenditures has been on the rise in recent years, the share of current transfer expenditures has shown higher increases, growing from $7.81 \%$ in 2015 to $9.27 \%$ in 2019 . The share of capital expenditures, which promises importance for investments, has also decreased in recent years. It is observed that the share of interest expenditures in GDP has increased in recent years.

Due to the contraction in Turkey in 2016, supports such as the use of cash and tax incentives to support production, investment and employment within the scope of expansionary fiscal policies in order to revive the economy, as well as the postponement of social security premium payments to the last quarter of the year in 2017 caused the central government budget deficit to increase. Tax amnesties were also made in 2016, 2017 and 2018 and when we look at the collection/accrual rates of tax revenues in these years, the rates are among the lowest among the collection/accrual rates realized throughout the history of the Republic of Turkey. In recent years, the burden that the legal framework 
for the establishment and operation of municipal hospitals according to the publicprivate partnership system, as well as the burden that the pass guarantee commitment on bridges and highways built may create on the budget are also issues that need to be emphasized. Again, the very low ratio of primary balance to GDP has aggravated the problems regarding the solvency of public debts.

In such a situation, within the scope of increasing public revenues and reducing public expenditures, it may be recommended to (i) be cautious about personnel expenses and current transfers, (ii) consider the burden that domestic and foreign debt interests may cause on the budget not to resort to extra-budgetary financing sources as much as possible, (iii) expand the tax base rather than increasing tax rates to boost tax revenues, (iv) prevent the informal economy, an ineffective tax system and tax audit deficiencies, (v) prevent frequent tax amnesties and ensure fiscal discipline for the primary surplus, which is considered an anchor of fiscal policy, (vi) consider the burden on the budget of commitments related to projects within the scope of public-private partnerships, and (vii) prioritize financial accountability. In addition, the main policy recommendations may be expressed as the implementation of a programme-based and performance-based budgeting system, which has the opportunity to be implemented in our country in 2021, the main backbone of which is the programming of public expenditures, and which prioritizes financial transparency and accountability, by being adopted by all public administrations. To ensure sustainability, it is also extremely important to eliminate market uncertainties, to prevent increases in inflation rates, which have been quite high in Turkey in recent years (the annual change in the CPI was $19.58 \%$ as of September 2021), to stay away from inflation-based growth, to maintain a balanced interest rate and exchange rate policy, making the interest-debt balance sustainable.

All these may be shown as some remedial policies for sustainability. Unless necessary remedial policies regarding budget imbalances are implemented, fiscal imbalances will lead to bigger and more painful adjustments for the economy. Considering the detrimental effects of permanent deficits, it is understood that practices regarding debt sustainability and appropriate fiscal policies are extremely important.

As a result of our conclusion that the budget deficits are unsustainable, it may be useful to compare the results of the cointegration sustainability tests with the method suggested by Bohn (1998) by making an analysis. This method tries to find out whether the primary surplus responds to changes in the debt-to-GDP ratio. This would be of interest for future research, as it would mean a substantial expansion of this article. 


\section{References}

Afonso, A. (2005). Fiscal Sustainability: The Unpleasant European Case. FinanzArchiv/Public Finance Analysis, 61(1), 19-44, https://www.jstor.org/stable/40913064, https://doi.org/10.1628/0015221053722532

Akar S. (2014). The Empirical Analysis of Budget Revenues and Expenditures in Turkey. Journal of BRSA Banking and Financial Markets, 8(1), 141-159, http://www.bddk.org.tr/Content/ docs/bddkDergiTr/dergi_0015_08.pdf

Aldama, P., Creel, J. (2019). Fiscal Policy in the US: Sustainable After All?. Economic Modelling, 81, 471-479, https://doi.org/10.1016/j.econmod.2018.03.017

Akkuş, Ö., Durmaz, A. (2019). Sustainability Budget Deficit in Turkey: Hidden Cointegration Relations. Finance Magazine, 176, 52-71, https://scholar.google.com. tr/citations?view_op=view_citation\&hl=tr\&user=3PZFQzgAAAAJ\&citation_for_ view=3PZFQzgAAAAJ:ULOm3_A8WrAC

Alagidede, P., Twenebohah, G. (2015). On the Sustainability of and Synchronization of Fiscal Policy in Latin America. Latin American Journal of Economics, 52(2), 213-240, http://dx.doi.org/10.7764/LAJE.52.2.213

Altun, N. (2017). Empirical Analysis of Sustainability Budget Deficit in Turkey: 1950-2015 Period. Journal of Economic and Social Research, 13(1), 13-22, https://dergipark.org.tr/en/ download/article-file/528790

Arghyrou, M. G., Luintel, K. B. (2003). Government Solvency: Revisiting Some EMU Countries. Royal Economic Society Annual Conference, 23-51, https://doi.org/10.1016/j. jmacro.2005.09.001

Baglioni, A., Cherubini, C. (1993). Intertemporal Budget Constraint and Public Debt Sustainability: The Case of Italy. Applied Economics, 25, 275-283, http:// doi.org/10.1080/00036849300000033

Baharumshah, A. Z., Soon, S-V., Lau, E. (2017). Fiscal Sustainability in an Emerging Market Economy: When does Public Debt Turn Bad?. Journal of Policy Modeling, 39, 99-113, https://doi.org/10.1016/j.jpolmod.2016.11.002

Belke, M. (2021). Fiscal Sustainability of Provincial Municipalities in Turkey: Dynamic Panel Data Analysis. Journal of Economics, Policy \& Finance Studies, 6(1), 128-158, https://doi.org/10.30784/epfad.824990

Brady, G. L., Magazzino, C. (2019). The Sustainability of Italian Fiscal Policy: Myth or Reality?. Economic Research-Ekonomska Istraživanja, 32(1), 772-796, https://doi.org/10.1080/1331 677X.2019.1583585

Büyükakın, F., Kapkara, S. (2018). Fiscal Sustainability Analysis: The Case of Turkey. International Management, Economy and Policy Congress,1-2 December, 970-979, ISBN: 978-605-81728-1-4

Bystrav, V., Mackiewicz, M. (2020). Recurrent Explosive Public Debts and the Long-run Fiscal Sustainability. Journal of Policy Modeling, 42, 437-450, https://doi.org/10.1016/j.jpolmod.2019.10.002 
Dickey, D. A., Fuller, W.A. (1979). Distribution of the Estimators for Autoregressive Time Series With a Unit Root. Journal of the American Statistical Association, 74(366), 421-431, https://doi.org/10.2307/2286348

Edwards, S. (2002). Debt Relief and Fiscal Sustainability. National Bureau of Economic Research Working Paper Series, 8939, http://dx.doi.org/10.1007/BF02659607

Enders, W. (1995). Applied Econometric Time Series. John Willey and Sons, Inc.

Fountas, S., Wu, J. L. (1996). Are the Greek Budget Deficit too Large?. Applied Economic Letters, 3, 487-490, http://dx.doi.org/10.1080/758540812

Göçer, İ., Aslan, R. (2020). Sustainability of Financial System: A New Generation Time Series Analysis for Turkey. Journal of Economic Sciences, 12(2), 163-178, https://dergipark.org. tr/en/pub/ebd/issue/57510/687697

Gürbüz, Y., Jobert, T., Tuncer, R. (2007). Public Debt in Turkey: Evaluation and Perspectives. Applied Economics, 39, 343-359, https://doi.org/10.1080/00036840500438889

Hakkio, C. S., Rush, M. (1991). Is the Budget Deficit too Large?. Economic Inquiry, 29(3), 429-445, https://doi.org/10.1111/j.1465-7295.1991.tb00837.x

Hamilton, J. D., Flavin, M. A. (1985). On the Limitations of Government Borrowing: A Framework for Empirical Testing. NBER Working Paper Series, 1632, https://www.nber.org/papers/ w1632, https://doi.org/10.3386/w1632

Harris, R., Sollis, R. (2003). Applied Time Series Modelling and Forecasting. Wiley, England. ISBN 0-470-84443-4

Kepenek, Y., Yentürk, N. (2003). Economy of Turkey (13th ed.). Istanbul: Remzi Publishing House, ISBN 13: 9789751407177

Kia, A. (2008). Fiscal Sustainability in Emerging Countries: Evidence from Iran and Turkey. Journal of Policy Modeling, 30(6), 957-972, https://doi.org/10.1016/j.jpolmod.2008.01.004

Kirchgassner, G., Wolters, J. (2007). Introduction to Modern Time Series Analysis. Springer, New York. ISBN 978-3-540-73290-7

Kirchgassner, G., Prohl, S. (2008). Sustainability of Swiss Fiscal Policy. Swiss Journal of Economics and Statistics, 144(1), 57-83, https://sjes.springeropen.com/track/ pdf/10.1007/BF03399249.pdf, https://doi.org/10.1007/bf03399249

Koo, C. M. (2002). Fiscal Sustainability in the Wake of the Economic Crisis in Korea. Journal of Asian Economics, 13, 659-669, https://doi.org/10.1016/S1049-0078(02)00178-1

Kuştepeli, Y., Önel, G. (2005). Fiscal Deficit Sustainability with a Structural Break: An application to Turkey. Review of Social Economic \& Business Studies, 5(6), 189-208, https://scholar. google.com.tr/citations?view_op=view_citation\&hl=en\&user=hC71niEAAAAJ\&citation_ for_view=hC71niEAAAAJ:2osOgNQ5qMEC

Kwiatkowski, D., Phillips, P. C. B., Schmidt, P., Shin, Y. (1992). Testing the Null Hypothesis of Stationarity against the Alternative of a Unit Root: How Sure are We that Economic Time Series have a Unit Root?. Journal of Econometrics, 54, 159-178, https://doi. org/10.1016/0304-4076(92)90104-Y 
Lian Chua, C., Perera, N., Suardi, S. (2021). Fiscal Regimes and Fiscal Sustainability in Sri Lanka, Applied Economics, 53(21), 2384-2397, https://doi.org/10.1080/00036846.2020.1859456

Maddala, G. S., Kim, I. M. (1998). Unit Roots, Cointegration and Structural Change. Cambridge, UK: Cambridge University Press. ISBN 978-0-521-58257-5.

Marinheiro, C. J. F. (2005). Sustainability of Portuguese Fiscal Policy in Historical Perspective. CESifo Working Paper, 1399, http://dx.doi.org/10.1007/s10663-006-9013-0

Mercan, M. (2014). Budget Deficits Sustainable? An Empirical Analysis for OECD Countries. Procedia - Social and Behavioral Sciences, 131, 258-263, https://doi.org/10.1016/j. sbspro.2014.04.114

Neaime, S. (2004). Sustainability of Budget Deficits and Public Debt in Lebanon: A Stationary and Co-integration Analysis. Review of Middle East Economics and Finance, 2(1), 43-61, http://dx.doi.org/10.1080/14753680410001685678

Nzimande, N. P., Ngalawa, H. (2019). Fiscal Policy Sustainability in SADC Countries. The African Finance Journal, 21, 86-97, https://www.researchgate.net/ publication/334654363_Fiscal_Policy_Sustainability_in_SADC_Countries

Olekalns, N., Cashin, P. (2000). An Examination of the Sustainability of Indian Fiscal Policy. The University of Melbourne Departments of Economics Working Paper Series, 748, https://econpapers.repec.org/scripts/redir.pf?u=http\%3A\%2F\%2Fwww.economics. unimelb.edu.au\%2Fdownloads\%2Fwpapers-00-01\%2F748.pdf;h=repec:mlb:wpaper:748

Özdemir, K. A. (2004). Public Debt in Turkey. The Central Bank of the Republic of Turkey Research Department Working Paper, No.04/11, https://tcmb.gov. tr/wps/wcm/connect/d60ed017-337f-474b-afe2-751b44eaf1ff/WP0411ENG. pdf?MOD=AJPERES\&CACHEID=d60ed017-337f-474b-afe2-751b44eaf1ff

Payne, J. E., Mohammadi, H., Cak, M. (2008). Turkish Budget Deficit Sustainability and the Revenue-expenditure Nexus. Applied Economics, 40(7), 823-830, https://doi.org/10.1080/00036840600749904

Peker, O., Göçer, İ. (2012). Empirical Analysis of Budget Deficits. Celal Bayar University Faculty of Economics and Administrative Sciences Journal of Management and Economics, 19(1), 163-178, https://dergipark.org.tr/en/pub/yonveek/issue/13696/165765

Prohl, S., Schneider F.G. (2006). Sustainability of Public Debt and Budget Deficit: Panel Cointegration Analysis for the European Union Member Countries. Department of Economics Johannes Kepler University of Linz, Working Paper No: 0610, http://www.econ.jku.at/papers/2006/wp0610.pdf

Quintos, C. E. (1995). Sustainability of the Deficit Process with Structural Shifts. Journal of Business \& Economic Statistics, 13(4), 409-417, https://doi.org/10.2307/1392386

Rubio, O.B., Roldan, C. D., Esteve, V. (2006). Is the Budget Deficit Sustainable when Fiscal Policy is Nonlinear? The Case of Spain, 1964-2001. Journal of Macroeconomics, 28(3), 596-608, https://doi.org/10.1016/j.jmacro.2004.08.002 
Slack, E., Bird, R. M. (2004). The Fiscal Sustainability of the Greater Toronto Area. International Tax Program, Institute for International Business, Joseph L. Rotman School of Management, University of Toronto, ITP Paper 0405, https://www.researchgate.net/ publication/24137642

Stubelj, I., Dolenc, P. (2010). Fiscal Sustainability of Eu Member States in the Context of Current Financial Crisis. Economic Research-Ekonomska Istraživanja, 23(4), 37-62, https://doi.org/10.1080/1331677X.2010.11517432

Telatar, E., Bolatoğlu, N., Telatar, F.(2004). A new approach on testing the behaviour of the governments towards sustainability of fiscal policy in a small-open and politically instable economy. Applied Economics Letters, 11, 333-336, https://doi.org/10.1080/1350485042000221643

Treahan, B., Walsh, C. E. (1991). Testing Intertemporal Budget Constraints: Theory and Application to US Federal Budget and Current Account Deficits. Journal of Money, Credit and Banking, 23(2), 206-223, https://doi.org/10.2307/1992777

Treasurer of Commonwealth of Australia (2002). Intergenerational Report 2002-03 (Budget Paper No.5). Australia: Canprint Communications. ISBN 0642741425

Ucal, M., Alıcl, A. (2010), Is Fiscal Policy Sustainable in Turkey?. Emerging Markets Finance \& Trade, 46(1), 83-93, https://doi.org/10.2753/REE1540-496X4603S106

Wilcox, D. W. (1989). The Sustainability of Government Deficits: Implications of the Presentvalue Barrowing Constraint. Journal of Money Credit and Banking, 21(3), 291-306, https://doi.org/10.2307/1992415

Woo, J. (2006). The Political Economy of Fiscal Policy: Public Deficits, Volatility and Growth. Germany: Springer-Verlag Berlin Heidelberg. ISBN-10 3-540-29640-9, ISBN-13 978-3-540-29640-9

World Bank (2014). Turkey Public Finance Review, Turkey in Transition: Time for a Fiscal Policy Pivot? Document of the World Bank, No. 85104-TR, http://hdl.handle.net/10986/19321 